\title{
The Determinants of Employee Attitude towards e-HRM-A Study of Engineering Company in Malaysia
}

\author{
Muhamad Khalil Omar, Siti Norizzati Khairul Fauzi, Azzarina Zakaria, Badrul Azmier Mohamed \\ Universiti Teknologi MARA, Selangor, Malaysia \\ khalil.omar@salam.uitm.edu.my
}

\begin{abstract}
Electronic Human Resource Management (e-HRM) is "...the application of information technology for both networking and supporting at least at least two individual or collective actors in their shared performing of HR activities" (Strohmeir, 2007). Using a survey method, this study reports the determinant of employee attitude towards e-HRM in an engineering company in Malaysia. There are basically two major independent variables i.e. perceived usefulness and perceived ease of use. The overall results show that the employees had significantly positive attitude towards e-HRM as they perceived that the system is useful and easy to use. Data shows that they intend to use e-HRM and predict that they would use e-HRM in future. The findings of this research provide valuable insights for the management to create a positive attitude towards technological interventions especially in assisting human resource management. Hence, a company should enhance the employees' understanding of the system through a proper and thorough training so that they will perceive the system as useful and easy to use.
\end{abstract}

Keywords: e-HRM; Electronic Human Resource Management; perceived usefulness; perceived ease of use; engineering company

\section{Introduction}

The Electronic Human Resource Management (e-HRM) is commonly associated with HRIS and V-HRM which it is not the same. HRIS is a Human Resource Information System which refers to ICT system used within HR department (Ruel, Bondarouk \& Looise, 2007). Whereas V-HRM or Virtual HRM is a network based structure built on partnerships and typically mediated by information technologies to help the organization acquire, develop, and deploy intellectual capital (Lepak \& Snell, 1998). It may have been a trend in this recent years that e-HRM is an essential in increasing the efficiency of HR management and have a great cost effective compared to traditional HR management. For example, the recruitment through website has given a bigger scale of candidates that can be reached anywhere and whenever they needed to. Recruitment has become easier to coordinate as the responses were instantaneous whilst selecting and comparing good candidates are now being done by just a click. There are basically three types of e-HRM. The first one is Operational e-HRM, which it is concerned about the administrative functions that normally related to payroll, employee personal data and records. Second is Relational e-HRM that is concerned with supporting the business process for example training, recruitment and performance management. The third is Transformational e-HRM that is concerned with the strategic human resource activities such as the knowledge management. These three types of e-HRM complete all the functions of human resource management in general.

The e-HRM can be easily said than done. The system normally needs a proper guidance if it was adapted from another company that created the system. Sometimes the system might work in a company but it may not work similarly in other company because of the different needs in each company. Hence, this study focuses on the employee attitudes with regards to implementation of e-HRM and a survey was conducted in an engineering company in Malaysia who had recently just implemented the system in February 2013. The system is known as Employee Self-service System (ESS) which is a tool to help the administrative tasks of human resource personnel. This system comprises of leave application, training records, online performance evaluation and more. This system were not only used for the purposes of human resource management alone but also included other support departments such as the IT request can be made online through ESS system as well. ESS basically is an intranet and extranet site for the 
employees to access all the provided services. Therefore, this research paper will investigate what influence employee attitudes towards the using of e-HRM and does perceived usefulness and perceived ease of use has a positive relationship with the employee attitudes towards e-HRM.

\section{Literature Review}

E-HRM: Electronic Human Resource Management (e-HRM) is known as an integrated optimization of HR processes consequently using web-based technology for all aspect of HR work. "Amongst other facets elearning in the field of continuing education, employee-self-service (ESS) in the field of HR administration and the utilization of the intra- and extranet in the field of recruitment belong to the main fields of e-HRM that are supported by the e-HRM system" (Erdoğmuş \& Esen, 2011). The term "...e-HRM was first used in the late 1990s when e-commerce was sweeping the business world" (Olivas-Lujan, Ramirez \& ZapataCantu, 2007). The e-HRM is commonly associated with HRIS and V-HRM which it is not the same. "HRIS is a Human Resource Information System which refers to ICT system used within HR department" (Ruel, Bondarouk, \& Van der Velde, 2007). Whereas V-HRM or Virtual-HRM is a "...network based structure built on partnerships and typically mediated by information technologies to help the organization acquire, develop, and deploy intellectual capital" (Lepak \& Snell, 1998). The e-HRM has grown as a strategic tool in managing human resource. It became an essence to all organization in achieving its goals. "The e-HRM provides the HR function with the opportunity to create new avenues for contributing to organizational effectiveness" (Yusoff, Ramayah, \& Ibrahim, 2010).

Attitude towards e-HRM: Technology Acceptance Model (TAM) developed by Davis (1989) is the most adapted model in e-HRM research pertaining attitudes towards e-HRM. The goal of TAM was "...to provide the explanation of the determination of computer acceptance that is generally capable of explaining user behavior across a broad range of end-user computing technologies and user populations, while at the same time being both parsimonious and theoretically justified" (Davis, 1989). TAM model was emphasized on the two major factors i.e. perceived usefulness and perceived ease of use. These two factors are important to determine an employee's attitude towards his or her intention to use and actual usage of Information System (IS). Perceived usefulness is defined as "...the degree to which an individual believes that using a particular system would enhance his or her job performance". Whereas perceived ease of use is defined as the degree to which an individual believes that using a particular system would be free of physical and mental effort (Davis, 1989). The reason that TAM model is chosen for this research is because TAM has been tested empirically and supported through validations, applications, and replications (Venkatesh, Morris, Davis \& Davis, 2003; Lee, 2010). TAM model has proved that it is one of the most powerful, robust and parsimonious model for predicting user acceptance especially in IS context (Bueno \& Salmeron, 2008).

Impact of Perceived Usefulness and Ease of Use With Regard to Attitude towards e-HRM: There has been numerous numbers of researches done on e-HRM. Yusoff, Ramayah and Ibrahim (2010) discovered that only attitude that has been found to influence the intention to use e-HRM technology. In the other study done by Yusoff and Ramayah (2012) shows that the variables of perceived usefulness and perceived ease of use have given significant effects on attitude towards using e-HRM. The e-HRM system "...obviously is not a strictly universal practice, it is appropriate for a certain type of organization while inappropriate for other organization" (Yusoff \& Ramayah, 2012). Somehow, e-HRM may not be appropriate for all organization as it is depended on the need and what is important for the organization. As for some small organization, investing in e-HRM may not benefit in terms of cost effective for them and managing small number of employees can still be efficient using conventional human resource management system. Ruel, Bondarouk and Looise (2007) in their research showed that positive actual use of e-HRM application got along with more positive perception of HR effectiveness and so do the easiness of use. Perceived usefulness and perceived ease of use are statically distinct construct because the effect of ease of use is the subset of those comprising in the usefulness brought from the system i.e. "...between two systems that perform the identical set of functions, a user should fine the one that is easier to use more useful" (Davis, 1989). Based on the reviewed literatures, a framework of study is developed as shown in Figure 1. 


\section{Methodology}

The main purpose of the research is to determine the factors that influence the employee attitude towards e-HRM. The data of the research were collected through questionnaires. The sample comprises of 53 employees of an engineering company in Malaysia, which were administered during a period of 6 weeks starting from April 29th to June 7th. Questionnaires were distributed directly to the employees and also through an online survey which were distributed by email. It was then analyzed using IBM Statistic 20. The questionnaire was divided into four main sections: a profile, attitude towards using e-HRM, perceived usefulness, and perceived ease of use section. In the profile section, it contains of socio-demographic characteristic of the respondents such as gender, job category level and their range of birth which classify them into Gen-Y, Gen-X and baby boomers. For this section of survey, a multiple choice question was used in which several choices of answers are provided for each question asked.

\section{Research Framework}

\section{Figure 1: Framework of Study}

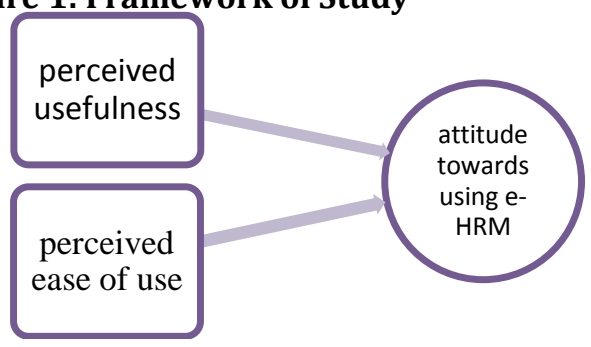

The survey was intended to understand and determine factors that influence the attitude of employees towards e-HRM where the independent variables of this study were put into assessment through this survey. The survey properly explored how the employees perceived the current system that they are using which whether it has brought usefulness to them and whether it is easy to use for them. Measures used in this study were adapted from prominent researchers i.e. Davis (1989) for perceived usefulness and perceived ease of use, while attitudes towards e-HRM was adapted from Voermans and Veldhoven (2007). The questions were structured using the Likert format where respondents are given seven choices for every question or statement. The choices represent the degree of agreement each respondent has on the given question. The Likert survey allows the researchers to carry out the quantitative approach effectively where the data can be interpreted by statistics.

\section{Results and Discussion}

The objective of this research is to determine whether the hypothesis developed for this study is accepted or rejected. The first hypothesis was there will be a positive relationship between perceived usefulness and attitude of employees towards e-HRM in an engineering company. This simply put that if there is a positive relationship then the more a system is perceived to be useful by employee the more positive the attitude of employees will be towards the system (e-HRM). Subsequently the second hypothesis was there will be a positive relationship between perceived ease of use and the attitude of employees towards eHRM in an engineering company. This second hypothesis merely suggested that the positive relationship will indicates that the more the system is perceived to be easy to be used by the employees, the more positive the attitude of employees towards the system (e-HRM).

Most of the 53 respondents surveyed in this study were female (68\%), Malay (77\%), Gen-Y (41\%), executive level (53\%). The results of this study in terms of all dependent and independent variables were significantly high in internal consistency as per the result of reliability analysis. The dependent variable of attitude towards e-HRM has a Cronbach's Alpha of .961 for its total items of 22. While for the two independent variables in this study which are perceived usefulness and perceived ease of use, both has .968 and .888 with total items of 10 each. As shown in Table 1, the Pearson correlation analysis, the results indicated that all variables are significantly and positively correlated to each other. Perceived usefulness 
and attitude towards e-HRM is positively and moderately correlated with .373 and its correlation is significant at the 0.01 level ( 2 tailed). The second independent variable is perceived ease of use where it is also positively and moderately correlated as well with .334 towards the dependent variables where correlation is significant at the 0.05 level ( 2 tailed). While perceived usefulness and perceived ease of use were significantly and highly correlated with each other at $.734(p=0.01)$. Therefore, it was concluded that all variables in this study were significantly and positively associated with each other. To further understand the effects of both independent variables in this study (i.e. perceived usefulness and perceived ease of use) towards the dependent variable (i.e. attitudes towards e-HRM), a regression analysis was conducted.

Table 1: Pearson Correlation Matrix

\begin{tabular}{llll}
\hline & $\begin{array}{l}\text { Perceived } \\
\text { Usefulness }\end{array}$ & $\begin{array}{l}\text { Perceived } \\
\text { Of Use }\end{array}$ & $\begin{array}{c}\text { EaseAttitudes towards } \\
\text { e-HRM }\end{array}$ \\
\hline Perceived Usefulness & $(.968)$ & & \\
Perceived Ease Of Use & $.734^{* *}$ & $(.888)$ & \\
Attitudes towards & $\mathrm{e}^{-} .373^{* *}$ & $.334^{*}$ & (.961) \\
HRM
\end{tabular}

Note. Coefficients alpha are in parentheses. ${ }^{* *}$. Correlation is significant at the 0.01 level (2-tailed). *. Correlation is significant at the 0.05 level (2-tailed).

Table 2: Regression Analysis

\begin{tabular}{llll}
\hline Variables & Coeff. (B) & $\begin{array}{l}\text { Std. } \\
\text { Error }\end{array}$ & Beta \\
\hline Intercept & 1.88 & .42 & \\
Perceived Usefulness & $.22^{*}$ & .09 & .22 \\
Perceived Ease Of Use & $.46^{*}$ & .08 & .50 \\
$\mathrm{R}^{2}$ & .38 & & \\
\hline Note. ${ }^{*} p<.01$. & & &
\end{tabular}

As shown in Table 2, both perceived usefulness and perceived ease of use were the significant positive determinants for attitudes towards e-HRM with both independent variables were explaining 38\% variations in the dependent variable. Additionally, Beta result shows that perceived ease of use was more important than perceived usefulness in predicting their positive effects towards attitudes towards e-HRM. Taken together, an employee's attitudes towards using e-HRM shall be significantly and positively influenced by the level of perceived ease of use he or she is having towards the e-HRM system and at the same time is depended upon the level of usefulness he or she perceived towards the system as well. Therefore, both hypotheses of this study have been supported and the regression equation for this study is: Attitudes towards using e-HRM $=1.88+0.22$ perceived usefulness +0.46 perceived ease of use

In overall the findings of this study suggest that the independent variables; perceived usefulness and perceived ease of use has a positive relationship towards the dependent variable; attitude towards using e-HRM. In summary, this study has achieved its objectives to identify the impact of perceived usefulness and perceived ease of use towards attitude using e-HRM among employees in an engineering company, as well as discovered which factors that better predicting the employees' attitude in using e-HRM which is the perceived ease of us of the system.

\section{Conclusion}

Based on the findings, it shows that both independent variables are positively correlated with dependent variables. Hence, if during the initial stage of implementation all employees should be given a proper and valid understanding on the system. This is because the more the system being understood by the employees the more they perceived the system is useful and easy to use. Based on the researchers own 
the observation and initial interview while collecting the data, the employees were mostly aware of the goals of the system towards themselves but not fully aware how this system was intended to be use for the purpose of improving their organization with a better human resource management. It is also important that the system is not only being evaluated by the end users but also evaluated in the perspective of the people who will administer the system. To have an effective system use in a company, it shall not only benefit one side which is the staff but gave a hard time towards the one managing or administered the staff throughout the system. As of the result of this study, it is clearly stated that both factors highlighted in this study have influence the attitude of employees towards e-HRM. However the study may neglect the other area or perspective of employees who are managing or administrating the staff through the system. A system would be effective and efficient if it give ease to both side of this group which is the employees and also the administrator including their manager. Other than that, for the future research the generation-Y phenomenon can be challenge on does the age range influence the attitude of employees towards e-HRM? It is said that generation-Y are more technologically optimistic, thus they adapt the technology more easily. Thus a research question regarding generation- $Y$ and attitude towards e-HRM can be studied.

\section{References}

Boundarouk, T. \& Looise, J. K. (2005). HR contribution to IT innovation implementation: results of three case studies. Creativity and Innovation Management, 14(2), 160-168.

Bueno, S. \& Salmeron, J. L. (2008). TAM-based success modeling in ERP. Interact. Comp, 20(6), 515-523.

Davis, F. D. (1989). Perceived usefulness, perceived ease of use, and user acceptance of information technology. MIS quarterly, 3, 319-340.

Erdoğmuş, N. \& Esen, M. (2011). An Investigation of the Effects of Technology Readiness on Technology Acceptance in e-HRM. Procedia-Social and Behavioral Sciences, 24, 487-495.

Lee, M. C. (2010). Explaining and predicting users' continuance intention toward e-learning: an extension of the expectation confirmation model. Comp. Edu., 54, 506-516.

Lepak, D. P. \& Snell, S. A. (1998). Virtual HR: Strategic human resource management in the 21st century. Human resource management review, 8(3), 215-234.

Olivas-Lujan, M. R., Ramirez, J. \& Zapata-Cantu, L. (2007). E-HRM in Mexico: Adapting innovations for global competitiveness. International Journal of Manpower, 28(5), 418-434.

Ruel, H. J., Bondarouk, T. V. \& Van der Velde, M. (2007). The contribution of e-HRM to HRM effectiveness: Results from a quantitative study in a Dutch Ministry. Employee Relations, 29(3), 280-291.

Strohmeier, S. (2007). Research in e-HRM: Review and implications. Human Resource Management Review, 17(1), 19-37.

Venkatesh, V., Morris, M. G., Davis, G. B. \& Davis, F.D. (2003). User acceptance of information technology: toward a unified view. MIS Quarterly, 27(3), 425-478.

Voermans, M. \& Veldhoven, M. V. (2007). Attitudes towards E-HRM: An empirical study at Philips. Personnel Review, 36(6), 887-902.

Yusoff, Y. M., Ramayah, T. \& Ibrahim, H. (2010). E-HRM: A proposed model based on technology acceptance model. Afr. J. Bus. Manage, 4(13), 3039-3045.

Yusoff, Y. M. \& Ramayah, T. (2012). Electronic human resource management (e-HRM) and human resource (HR) competencies: some evidence from an emerging market. International Journal of Information and Communication Technology, 4(1), 27-39. 